\title{
Spectrophotometric Determination of Trace Elements in various Honey Samples, Collected from different Environments
}

\author{
Afzal Shah ${ }^{1,2, *}$, Farzana Sikandar ${ }^{1}$, Imdad Ullah ${ }^{23}$, Afzal Shah ${ }^{3}$, Salah Ud-Din Khan', Usman Ali Rana ${ }^{2,4}$, Thomas McCoy ${ }^{2}$ \\ ${ }^{1}$ Department of Chemistry, University of Science and Technology, Bannu 28100, Khyber Pakhtunkhwa, Pakistan \\ ${ }^{2}$ School of Chemistry, Monash University, Clayton, Melbourne, VIC 3800, Australia \\ ${ }^{3}$ Department of Chemistry, Quaid-i-Azam University, Islamabad 45320, Pakistan \\ ${ }^{4}$ Deanship of scientific research, College of Engineering, PO Box 800, King Saud University, Riyadh 11421, Saudi Arabia \\ *Corresponding author: afzalnm@yahoo.com
}

Received July 26, 2014; Revised August 15, 2014; Accepted August 18, 2014

\begin{abstract}
Honey is an important food ingredient due to its nutritive and medicinal values. In this project, varieties of honey samples were collected from different environmental sites in District Bannu. Several spectroscopic techniques were used to determine the composition of a series of trace elements within these samples. $\mathrm{Cu}, \mathrm{Zn}, \mathrm{Al}, \mathrm{Fe}$ and $\mathrm{Mg}$ composition was determined using flame atomic absorption spectroscopy (FAAS), meanwhile $\mathrm{Pb}, \mathrm{Ni}, \mathrm{Cd}$ and $\mathrm{Cr}$ composition was determined by electro-thermal atomic absorption spectroscopy (ETAAS) and graphite atomic absorption spectroscopy (GAAS). Lastly, As, Hg, and Se composition was determined by Hydride generation atomic absorption spectroscopy (HGAAS). The trace elements $\mathrm{Al}, \mathrm{Zn}, \mathrm{Mg}, \mathrm{Fe}, \mathrm{Cu}, \mathrm{Cr}, \mathrm{Pb}, \mathrm{Cd}$ and $\mathrm{Ni}$ were found in considerable abundances. However the amounts of $\mathrm{As}, \mathrm{Hg}$ and Se were below the detection limits of the instrument ( $\geq 0.1 \mathrm{ppm}, \geq 0.1 \mathrm{ppm}$ and $\geq 0.2 \mathrm{ppm}$ for each element respectively).
\end{abstract}

Keywords: trace elements, honey, food, nutrition, environment

Cite This Article: Afzal Shah, Farzana Sikandar, Imdad Ullah, Afzal Shah, Salah Ud-Din Khan, Usman Ali Rana, and Thomas McCoy, "Spectrophotometric Determination of Trace Elements in various Honey Samples, Collected from different Environments." Journal of Food and Nutrition Research, vol. 2, no. 9 (2014): 532-538. doi: 10.12691/jfnr-2-9-1.

\section{Introduction}

Honey is a sweet food that is produced by Honeybees. The bees extract nectar from different flowers and combine it with proteins and enzymes, which collectively is then stored in their honeycomb [1]. Honey has low surface tension and heat conductivity. It appears in different colors and strongly hygroscopic [2]. Honey contains variety of macro and micronutrients in the form of supersaturated sugars, organic acids, proteins, aroma compounds, tannins, enzymes, vitamins and traces of minerals. Humankind uses honey as a popular condiment, natural sweetener and household remedy product $[3,4,5,6]$. The exact composition of honey depends on the floral sources from which the nectar is harvested [7].

Trace elements are very important for life but can also potentially have harmful effects. Some metals ( $\mathrm{Fe}, \mathrm{Zn}, \mathrm{Cu}$, and $\mathrm{Mn}$ ) play important roles in biological systems and are therefore referred to as essential elements, while others are non-essential elements $(\mathrm{Pb}, \mathrm{Cd})$. The non-essential elements can be toxic even in trace amounts $[8,9,10,11,12]$. While, essential metals can also be harmful if taken in the greater amounts than the recommended values $[13,14,15,16]$. Honey possesses a large range of properties and is considered a nutritious food, and therefore it must be free of all toxic elements. The mineral composition of honey differs depending on the plant sources and environments from which it originates. For example, light Blossom honeys have a lower content of trace elements than darker honeys such as honey dew, chestnut and heather $[17,18,19]$.

The relationship between bees and man has been evident since the stone age. Honey was used as a medicine and an ointment since 2100-2000 BC. Its most prominent healing applications are in the treatment of wounds, burns and infections [20]. Honey possesses antibacterial and antimicrobial characteristics [21,22,23,24]. Honey contains significant antioxidant compounds including ascorbic acid, glucose oxidase, catalase, flavonoids, phenolic acids, carotenoid derivatives and organic acids. Hence, it is considered as a healthy ingredient for liver functions and serum glucose level $[25,26]$.

Analyses of trace elements in honey samples provide a more accurate indication for the presence of contaminants in environments. In Turkey, 21 honey samples have been collected and analyzed for $\mathrm{Ni}, \mathrm{Mn}, \mathrm{Fe}, \mathrm{Cu}, \mathrm{Cd}$ and $\mathrm{Mg}$ using Atomic Absorption Spectroscopy (AAS) [27]. Trace element analyses are extremely important in regards to the quality control of food and diet. Some studies have applied Inductively Coupled Plasma Mass Spectrometry 
to uncover metal contents in honey samples and have proposed that honey is a nutritious and safe food [28]. Meanwhile, other studies have discovered trace amounts of $\mathrm{Cu}, \mathrm{Pb}, \mathrm{Cd}$ and $\mathrm{Zn}$ in honey samples using Differential Pulse Anodic Stripping Voltammetry [29]. Different analytical techniques have been applied in exploring the metal composition of honey samples and hence, honey can be considered as a useful bio-indicator of environmental pollution [30-36].

Given that honey is a highly sought after food ingredient and has great potential for medicinal applications, the current studies were aimed to reveal the presence of trace amounts of trace elements in the subject honey samples, and to also explore the effect that the environment has on the quality and nutritional value of honey.

\section{Material and Method}

\subsection{Material}

All the glassware used in these analyses was soaked in $10 \% \mathrm{v} / \mathrm{v} \mathrm{HNO}_{3}$ overnight, then washed with deionized water and finally rinsed with double distilled water prior to analysis. Analytical grade chemicals and reagents were used throughout the experiments. Atomic Absorption Spectrophotometer (Hitachi Z-8000, Japan) connected to a Graphite furnace and a microprocessor with a Zeeman background correction were used for the determination of trace elements in honey samples.

\subsection{Sampling}

Various samples of honey were collected from different areas (Miryan, Baka khel, Ghoriwala, Kakki, Sorani and Domail) of District Bannu. Each sample was approximately $250 \mathrm{~g}$. Sampling was done in the months of May and June. All samples were placed in $100 \mathrm{~mL}$ plastic bottles and were stored at room temperature.

\subsection{Sample Pretreatment}

The determination of trace elements and contaminants in honey required extensive sample preparation prior to instrumental analysis. Hence, a wet digestion method was employed in which the organic matter was digested with the help of oxidizing agents. $5 \mathrm{~mL}$ of sulphuric acid and $20-30 \mathrm{~mL}$ of nitric acid were added to the samples. The nitric acid destroyed the bulk of the organic matter but it was not enough to completely destroy all traces. So, the samples were boiled and evaporated off during the digestion process until only the sulphuric acid remained. Finally, dense, white sulfur trioxide fumes were evolved and began to reflux in the flask. While the solution was very hot, the $\mathrm{H}_{2} \mathrm{SO}_{4}$ worked to remove the remaining organic material. This entire process was carried out in a fume hood $[37,38]$.

\subsection{Preparation of Standard Solutions of Metals}

1000 ppm standard solutions of each element (Al, As, $\mathrm{Cd}, \mathrm{Cr}, \mathrm{Cu}, \mathrm{Fe}, \mathrm{Mg}, \mathrm{Ni}, \mathrm{Pb}, \mathrm{Se}, \mathrm{Zn}$ and $\mathrm{Hg}$ ) were prepared by dissolving the respective metal or its salt in $\mathrm{HNO}_{3}$, followed by dilution with double distilled water.

\subsection{Use of Chemical Modifiers in GFAAS}

Chemical matrix modifiers were used in Graphite Furnace Atomic Absorption Spectroscopy (GFAAS) in order to stabilize the analyte and volatilize the bulk of the sample matrix. Moreover, background signals and chemical interferences present in the sample were removed by the use of modifiers in the form of magnesium nitrate and ammonium dihydrogen phosphate [39].

\subsection{Analytical Method}

For GFAAS, the instrument consisted of a premix burner (water cooled, fishtail type) with a $10 \times 0.05 \mathrm{~cm}^{2}$ slot. In addition, a monochromator with a diffraction grating of 1800 grooves/mm, wavelength range of 190 $900 \mathrm{~nm}$, focal length of $450 \mathrm{~nm}$ and giving an average dispersion of $1.2 \mathrm{~nm} / \mathrm{mm}$ was positioned. An airacetylene flame was used with an oxidant pressure of 1.60 $\mathrm{kg} / \mathrm{cm}^{2}$. As a source of radiation, neon-filled hollow cathode lamps were used. Firstly, a blank solution was run by the instrument to retrieve the background signals. Then standard solutions of each element were measured to optimize the instrument response, and finally sample solutions of honey were analyzed in order to determine the concentration of each trace element. Lead, nickel, cadmium and chromium composition was determined by electro-thermal atomic absorption spectroscopy. Meanwhile arsenic, selenium and mercury were analyzed by a hydride generation technique. Lastly, the analysis of copper, zinc, aluminium, iron and magnesium was done by flame atomic absorption spectroscopy. Of all these metals, Mercury, Arsenic and Selenium were found to be present in quantities below the detection limit of the instrument. The detection limit for Selenium was $\geq 0.2$ ppm and for Mercury and Arsenic $\geq 0.1 \mathrm{ppm}$.

\section{Results and Discussion}

\subsection{Determination of Aluminium:}

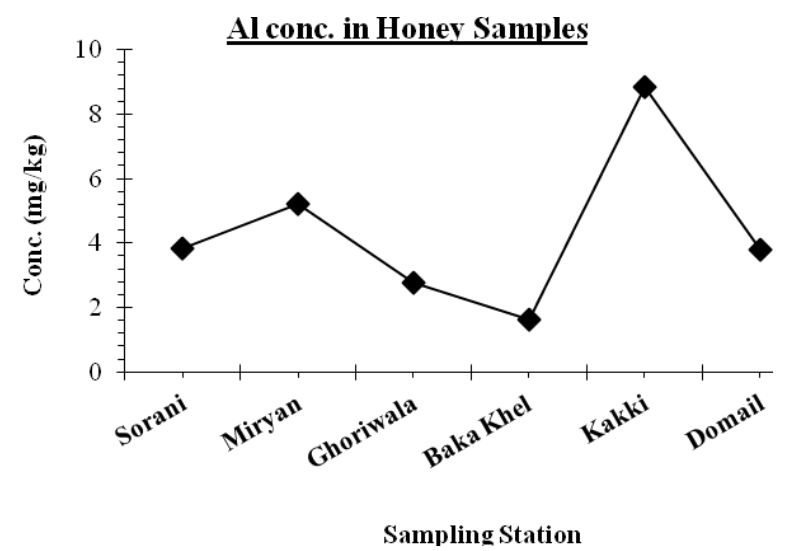

Figure 1. Aluminum; FAAS, Wavelength (309.3 nm), Lamp current (7.5 mA), Fuel pressure $\left(0.20 \mathrm{Kg} / \mathrm{cm}^{2}\right)$

Figure 1 demonstrates the large range of concentrations of aluminium (Al) in the different honey samples. These variations stem from the differing climatic conditions as well as the floral sources from which the Honeybees extract the nectar. Plants absorb these minerals from the 
water and soil, and the Honeybees then suck the nectar from these plants which contains these minerals [34]. Honey from Sorani and Miryan have a very similar concentration of Al. The minimum value was found in the region of Baka Khel and the maximum value was found in the area of Ghoriwala (Figure 1). Literature values of $\mathrm{Al}$ have been reported in the range of $0.25-14.25 \mathrm{mg} / \mathrm{kg}$ in Chilean honey [32], Excess amounts of this metal in honey has been linked with Alzheimer's disease [40]. 2.40 - $16.91 \mathrm{mg} / \mathrm{kg}$ in Moroccan honey [41], $0.00257 \mathrm{mg} / \mathrm{kg}$ in the area of Kazanlak [42], 0.88 - 3.04 mg/kg in Argentina [43] and $22.8 \mathrm{mg} / \mathrm{kg}$ [44].

\subsection{Determination of Zinc}

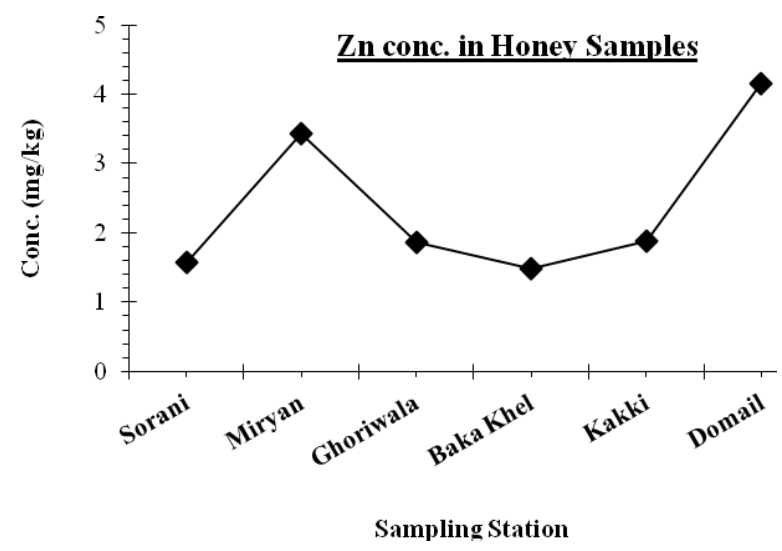

Figure 2. Zinc, FAAS, Wavelength (213.8 nm), Lamp current (10.0 $\mathrm{mA})$, Fuel pressure $\left(1.60 \mathrm{Kg} / \mathrm{cm}^{2}\right)$

It is evident from Figure 2 that the higher and lower amounts of $\mathrm{Zn}$ were observed in honey samples from Miryan and Baka Khel areas respectively. For honey samples collected from areas in Baka Khel and Sorani, concentrations of $\mathrm{Zn}$ were very similar. This was also the case for the honey samples collected from Ghoriwala and Domail (Fig. 2). The reported values of $\mathrm{Zn}$ in honey samples are in the range of $0.0011-0.0242 \mathrm{mg} / \mathrm{g}$ in honey from Turkey [35], 0.98 - $2.28 \mathrm{mg} / \mathrm{kg}$ in Moroccan honey [41], $0.30-1.26 \mathrm{mg} / \mathrm{kg}$ in the Kazanlak region of Central Bulgaria [42], $0.00108 \mathrm{mg} / \mathrm{g}$ for Argentinian honey [43], $0.00115-0.00495 \mathrm{mg} / \mathrm{g}$ [45] and $0.00018-0.0191 \mathrm{mg} / \mathrm{g}$ in the Canary Islands [46].

\subsection{Determination of Iron}

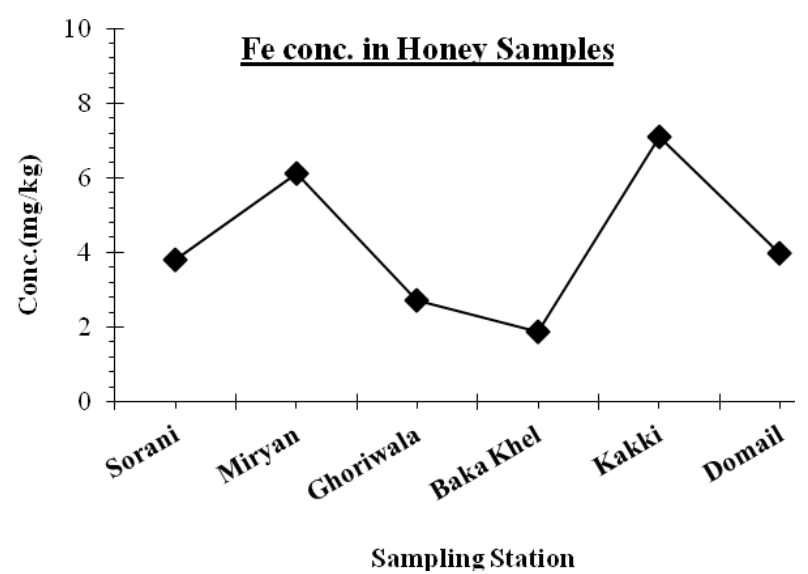

Figure 3. Iron; FAAS, Wavelength (213.8 nm), Lamp current (10 mA), Fuel pressure $\left(1.60 \mathrm{Kg} / \mathrm{cm}^{2}\right)$
Figure 3 indicates that the lowest Fe concentration was found in honey samples collected from Baka Khel, and the highest value was found in Miryan. Literature values of Fe concentration in various honey samples are $0.0052-0.001$ $\mathrm{mg} / \mathrm{g}$ in regions of Turkey [35], $1.24-4.31 \mathrm{mg} / \mathrm{kg}$ in Kazanlak [42], $0.00391 \mathrm{mg} / \mathrm{kg}$ in regions of Argentina [43], $0.00345-0.00894 \mathrm{mg} / \mathrm{g}$ [45], $0.0004-0.05251 \mathrm{mg} / \mathrm{g}$ in the Canary islands [46], $1.54 \mathrm{mg} / \mathrm{kg}$ [47], $13.5 \mathrm{mg} / \mathrm{kg}$ in Zulia State [48] and 2.55 - $3.50 \mathrm{mg} / \mathrm{kg}$ in honey samples analyzed by N. Matei [49].

\subsection{Determination of Magnesium}

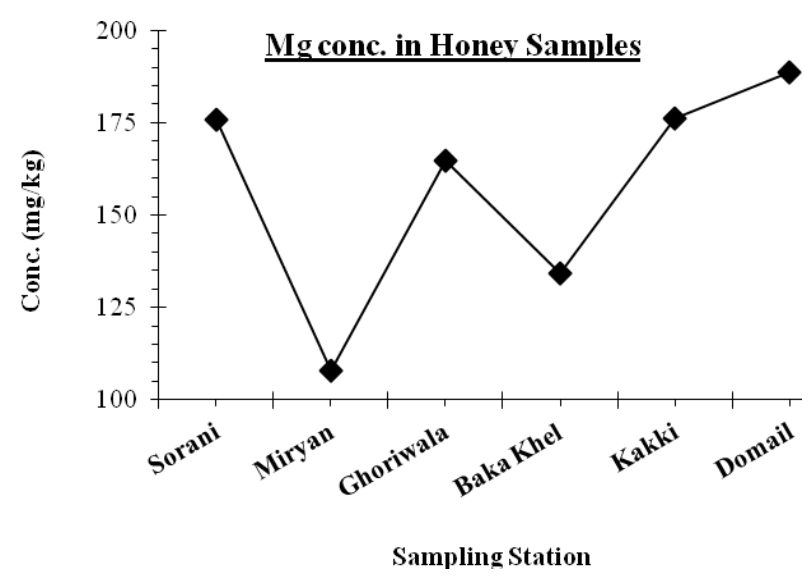

Figure 4. Magnesium; FAAS, Wavelength (285.2 nm), Lamp current (7.5 mA), Fuel pressure $\left(1.60 \mathrm{Kg} / \mathrm{cm}^{2}\right)$

Figure 4 shows that Honey samples from Miryan and Domail have the lowest and highest concentrations of Magnesium respectively. From literature, it can be seen that the levels of Magnesium present in honey samples taken from various regions of District Bannu are significantly higher than those quoted by other studies. $\mathrm{Mg}$ concentrations of 0.58 - $16 \mathrm{mg} / \mathrm{kg}$ were reported in Moroccan honey [41], 8.8 - $19.9 \mathrm{mg} / \mathrm{kg}$ for honey from the Kazanlak area [42], $0.02338 \mathrm{mg} / \mathrm{g}$ in an Argentinian region [43] and $52 \mathrm{mg} / \mathrm{kg}$ in Zulia state, Venezuela [48].

\subsection{Determination of Copper}

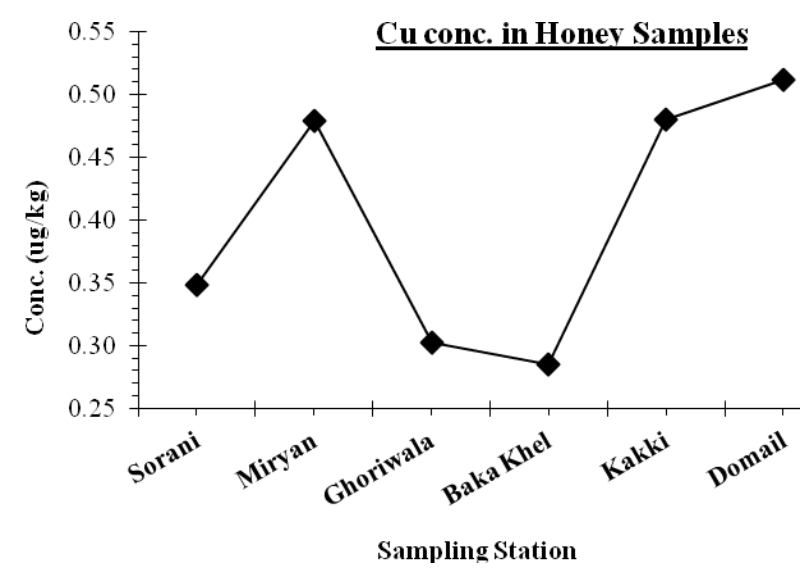

Figure 5. Copper; FAAS, Wavelength (324.8 nm), Lamp current (7.5 $\mathrm{mA})$, Fuel pressure $\left(1.60 \mathrm{Kg} / \mathrm{cm}^{2}\right)$

Figure 5 shows that the concentrations of copper in various honey samples analyzed in this study are higher than some of the reported values [43,51] while being lower than others $[41,42,45,50,57]$. The literature quotes 
that the $\mathrm{Cu}$ content in numerous honeys is: 0.25 - 1.10 $\mu \mathrm{g} / \mathrm{g}$ in Turkey [35], 233 - $878 \mu \mathrm{g} / \mathrm{kg}$ in Morocco [41], 90 - $250 \mu \mathrm{g} / \mathrm{kg}$ in the Kazan lake region [42], $0.19 \mu \mathrm{g} / \mathrm{kg}$ in Argentina [43], $0.25-1.30 \mu \mathrm{g} / \mathrm{g}$ in the Black Sea region of Turkey [45], $1.8 \mu \mathrm{g} / \mathrm{g}$ in south eastern Anatolia, Turkey [50] and $0.31 \mu \mathrm{g} / \mathrm{g}$ in Central Italy [51].

\subsection{Determination of Nickel}

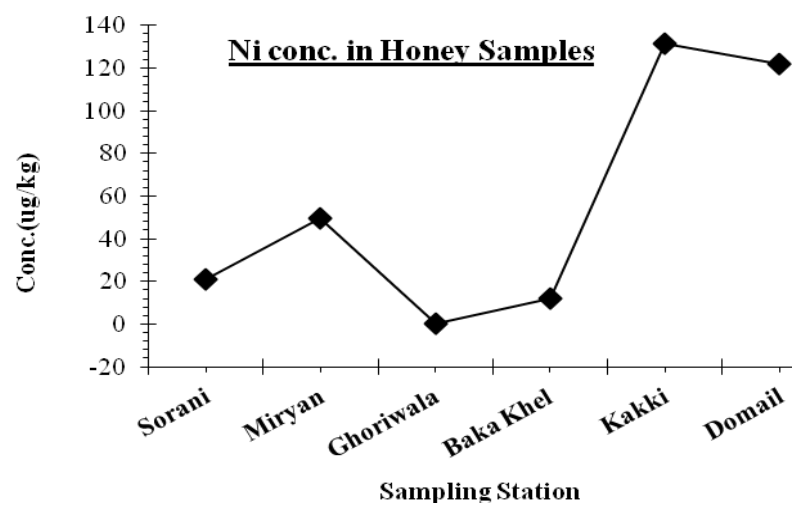

Figure 6. Nickel; ETAAS, Wavelength (232.0 nm), Lamp current (7.5 $\mathrm{mA}$ ), Flow rate (Argon gas) $200 \mathrm{ml} / \mathrm{min}$

Figure 6 shows the highest concentrations of $\mathrm{Ni}$ in Kakki while lowest in Ghoriwala. In literature, Ni contents are reported as being $0.01-1.04 \mathrm{mg} / \mathrm{kg}$ [32], 78 - 420 $\mu \mathrm{g} / \mathrm{kg}$ [41], $1020 \mu \mathrm{g} / \mathrm{kg}$ [42], $1030-2500 \mu \mathrm{g} / \mathrm{kg}$ [49], $1250-4100 \mu \mathrm{g} / \mathrm{kg}[50]$ and $308 \mu \mathrm{g} / \mathrm{kg}$ [52].

\subsection{Determination of Chromium}

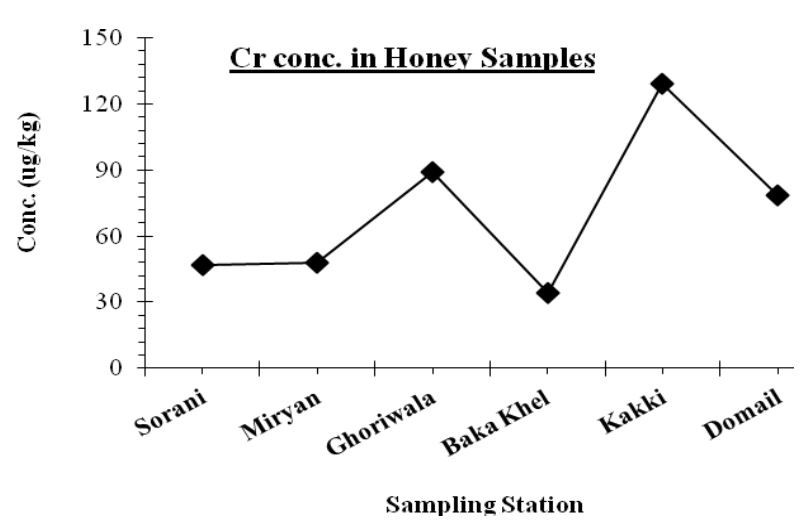

Figure 7. Chromium; ETAAS, Wavelength (359.3 nm), Lamp current (7.5 mA), Flow rate (Argon gas), $200 \mathrm{ml} / \mathrm{min}$

Figure 7, reveals that the honey samples from Kakki and Baka Khel contain highest and lowest concentrations of $\mathrm{Cr}$ respectively. In literature, the $\mathrm{Cr}$ concentration varies in different honey samples as, 30 - $1900 \mu \mathrm{g} / \mathrm{kg}$ [32], $20 \mu \mathrm{g} / \mathrm{kg}$ [42] and 40 - 800 $\mu \mathrm{g} / \mathrm{kg}$ [49].

\subsection{Determination of Lead}

Figure 8 shows the concentrations of lead in the subject honey samples. In the literature, values of $\mathrm{Pb}$ in honey samples were reported as being 17.6 - $32.1 \mu \mathrm{g} / \mathrm{kg}$ [35], 12.9 - $46 \mu \mathrm{g} / \mathrm{kg}$ [41], less than $200 \mu \mathrm{g} / \mathrm{kg}$ [42], 30.3 - 58.6 $\mu \mathrm{g} / \mathrm{kg}$ [45], $4200-6300 \mu \mathrm{g} / \mathrm{kg}$ [50], $48 \mu \mathrm{g} / \mathrm{kg}$ [53], 340 $\mu \mathrm{g} / \mathrm{kg}$ [54] and 8 - $38 \mu \mathrm{g} / \mathrm{kg}$ [55]. In our studies, some variations from the cited literature were observed.

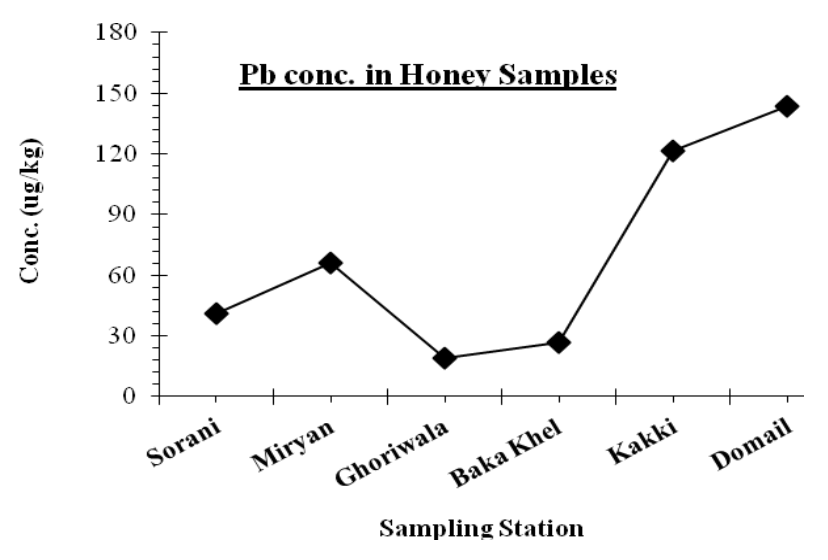

Figure 8. Lead; ETAAS, Wavelength (283.3 nm), Lamp current (7.5 $\mathrm{mA}$ ), Flow rate (Argon gas), $200 \mathrm{ml} / \mathrm{min}$

\subsection{Determination of Cadmium}

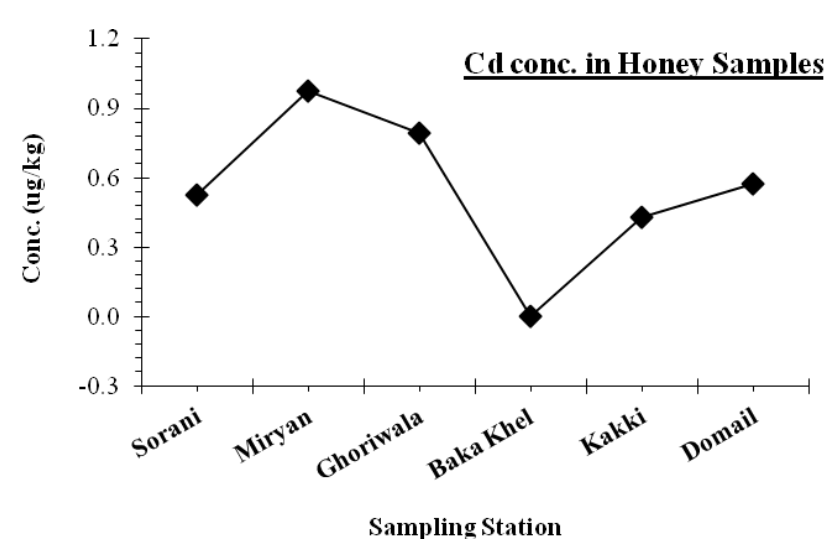

Figure 9. Cadmium;, ETAAS, Wavelength (228.8 nm), Lamp current (4.0 mA), Flow rate (Argon gas), $200 \mathrm{ml} / \mathrm{min}$

Figure 9 reveals that honey samples from Miryan and Bakka Khel contain highest and lowest Cd concentrations respectively. In literature, different concentrations of Cd are proposed in various honey samples as, $11.8-21.2 \mu \mathrm{g} / \mathrm{kg}$ [35], $8 \mu \mathrm{g} / \mathrm{kg}$ [36], $4 \mu \mathrm{g} / \mathrm{kg}$ [41], $20 \mu \mathrm{g} / \mathrm{kg}$ [42], 5.23 $9.28 \mu \mathrm{g} / \mathrm{kg}$ [45], $15 \mu \mathrm{g} / \mathrm{kg}$ [53] and 2 - $63.0 \mu \mathrm{g} / \mathrm{kg}$ [56].

High concentrations of $\mathrm{Al}$ may be due to Bee keeping activities and possibly from the containers used for the storage of the honey. Investigation into the $\mathrm{Al}$ contents of honey samples to uncover possible sources of contamination caused by this metal may be helpful to beekeepers for preventative purposes. The analyte honey samples were found to have greater concentrations of Aluminium compared to most of the cited literature.

Zinc (Zn) is an essential trace mineral for human health as it is an important component of many biological catalysts. Zinc plays a vital role in wound healing, disease resistance and is a co-factor for many enzymes. Also, zinc deficiency is common in patients with sickle cell disease. The variations in $\mathrm{Zn}$ content between the different localities is not only due to varying amounts of minerals in the soil, but also because of the different types of plants visited by the Bees. Honeybees fly up to $4 \mathrm{~km}$ in any direction in search of nectar and can easily cover an area of approximately $50 \mathrm{~km}^{2}$. The geochemical environment of these Bees' habitat greatly affects the quality and nutritional values of their honey. The concentration of $\mathrm{Zn}$ in honey samples from District Bannu is larger than the cited values. 
Honey contains a wide variety of minerals with a mean composition of $0.17 \%$. Iron $(\mathrm{Fe})$ is one of the essential trace minerals that is vital for life and has unique roles in the body. Fe is the center of the protein tetramer hemoglobin, which is essential for the transport of oxygen and carbon dioxide through the bloodstream. Therefore, its suitable amount must be present in all food ingredients. The differing concentrations of iron can be attributed to the climatic conditions of the locality under observation. The iron concentrations found in honey samples collected from the several regions of District Bannu are comparatively higher than the iron concentrations described in the cited literature, aside from Zulia State.

These difference in the concentration of $\mathrm{Mg}$ in the studied honey samples may be due to the disparity in soil composition of each particular area. If honey is to be considered an 'ideal food', it must provide the body with all essential nutrients. Magnesium is recognized as being a member of this class of nutrients, as it is needed by the body to facilitate many physiological functions. Mg plays a vital role in energy metabolism and ATP synthesis, and acts as a co-factor for approximately 300 different enzymatic reactions. A deficiency in $\mathrm{Mg}$ causes many undesirable symptoms such as muscle tension, headaches and neck pain. Honey is a rich source of $\mathrm{Mg}$ that can fulfill the daily nutritional requirement for this mineral.

Copper is essential for good health because it plays an integral role in the formation of hemoglobin. It serves to mobilize the iron, thus facilitating the transport of oxygen throughout the body.

In the area of Domail, the concentrations $\mathrm{Ni}$ was below the detection limit of the instrument. Significant variations in the concentration of $\mathrm{Ni}$ may be due to differences in the chemical composition of the soil at each location, as well as the existence of different kinds of plants. The role of different types of fertilizers may also contribute in this regard. $\mathrm{Ni}$ is an essential trace mineral required in only very minute amounts, and/or else it can exhibit carcinogenic effects. The intake of excess $\mathrm{Ni}$ causes chronic bronchitis and cancer of the lungs. Honey samples from District Bannu have higher concentrations of $\mathrm{Ni}$ when compared to honey samples of Chile, but lower values than those expressed in the other citations.

Variations in $\mathrm{Cr}$ concentrations may be due to a combination of certain factors like botanical, geochemical and anthropogenic activity. In order for the quality of honey to be maintained, each of these factors must be taken into consideration. The equipment used to store honey can also contaminate honey samples with trace elements.

The high concentration of $\mathrm{Pb}$ may be due to the small distance of Bee's colonies from the roads in the concerned area. High concentrations of $\mathrm{Pb}$ are lethal and can result in heart attacks, unconsciousness and hypertensive diseases. The main source of $\mathrm{Pb}$ pollution is from industrial wastes and vehicle's smoke. Honeybees travel considerable distances to collect nectar from different plants, and hence over the course of these lengthy journeys, have a high propensity to pick up unwanted materials and introduce these to the honey as a contaminant. This is likely to increase the amount of $\mathrm{Pb}$ in honey. The highest concentration of $\mathrm{Pb}$ is not suitable for consumption. Hence, honey from District Bannu has considerable contamination of $\mathrm{Pb}$.
The concentration Cd in honey samples from Baka Khel was below the detection limit of instrument. The acceptable value for $\mathrm{Cd}$ concentration in a food product is $0.0001 \mu \mathrm{g} / \mathrm{kg}$. Therefore in most of the studied honey samples, there was a clear $\mathrm{Cd}$ contamination. Excess amounts of $\mathrm{Cd}$ cause renal problems by interfering with kidney filtration processes. It is one of the more toxic elements and is mainly introduced to the environment by anthropogenic activity.

Reported concentrations of arsenic in honey samples are quite diverse depending on the location from which the sample is taken: $4.28 \mu \mathrm{g} / \mathrm{g}$ and $14-26 \mu \mathrm{g} / 100 \mathrm{~g}$ [5, 20]. In agricultural zones, the use of different types of pesticides and fertilizers are the main sources of arsenic. Hence, it may be present in trace amounts in the environmental water and absorbed by plants. The presence of arsenic in honey samples poses a serious health risk, as it is carcinogenic in nature. The honey samples collected from various regions of District Bannu seemed to lack arsenic in any significant quantity, or may be below the detection limit $(\geq 0.1 \mathrm{ppm})$ of the instrument. Hence, honey produced or marketed in Bannu can be considered nutritionally safe concerning this metal.

Mercury has very negative effects on human health. Thus, the study of such a toxic metal is helpful for assessing the environmental conditions of certain areas, and how these conditions can impact on the nutritional status of honey. Mercury is capable of crossing the bloodbrain barrier, and therefore can be fatal to humans, especially when it is biomethylated. Mercury toxicity can result in severe damage to the central nervous system, leading to impaired cognitive and motor functioning and eventually death. In this study, the concentrations of $\mathrm{Hg}$ were also found to be below the detection limit $(\geq 0.1 \mathrm{ppm})$ of the instrument. Therefore, the consumption of honey harvested from District Bannu is unlikely to cause $\mathrm{Hg}$ poisoning.

The major function of selenium is as an antioxidant, protecting the cells and immune system from free radicals produced as a result of oxidation. The concentration of selenium in honey varies from region to region depending on the makeup of the soil and water. Similarly to mercury and arsenic, selenium was also not found in traceable amounts in the honey samples from District Bannu. Hence, it is likely that this metal may also be below the detection limit $(\geq 0.2)$ of the instrument.

\section{Conclusion}

Nowadays, the threat of pollution is a growing concern as it is increasing astronomically. Hence, the honey produced and marketed in District Bannu can be considered nutritionally safe regarding the negligible contamination by As, Hg, and Se. Environment affects the composition of honey. Hence, it may be used as BioIndicator for monitoring the environmental pollution.

\section{Acknowledgement}

The authors would like to appreciate the Higher Education Commission (HEC), Islamabad, Pakistan for research support fellowship as well Fatima $\mathrm{Bi}$, principal 
officer in PCSIR, Laboratories, Karachi, Pakistan for technical support and the Deanship of Scientific Research at King Saud University for their funding of this research through the Research Group Project no RGP-VPP-255.

\section{References}

[1] White, J.W., Landis, W.D. "Honey composition and properties", Beekeeping in the US Agriculture. USA Hand book 1980, 335.

[2] Jusbin, O.S., "Chemical composition and application", In: Bee Products 1, 25-26, 1996.

[3] Hak, C.G., Kyoo H.M., Gil K.J. "The chemical composition of Korean honey” Korean Food Science and Technology 20, 631-636, 1998.

[4] Ball, David W., "The chemical composition of honey" Chemical education 84, 1643-1646, 2007.

[5] Bansal, V., Medhi, B., Pehndi P., "A remedy rediscovered and its therapeutic utility" Kathmandu University Medical Journal 3, 305-309, 2005

[6] Gilani, M., Kamal A., Raza, S., Rashid, N., Hameed T., "Comparative study of honey collected from different flora of Pakistan” Biological Sciences 2, 626-627, 2002.

[7] White, J.W., Reithof, M.L., Subers, M.H., Kushnir, I., "Composition of American honey" US Department of agriculture technical bulletin 1261, 11-24, 1962.

[8] Teng, J.H., Wang, T.L., Lin, W.C., Chin, M.T., Chen, Z.S., "Investigation on four heavy metal constituents of commercial restorative Chinese medicines" Food and Drug Analysis 3, 193202, 1995.

[9] Dundar, M.S., Deryaoglu, N., "Heavy metal determination in outdoor atmosphere dust depositions" Fresenius Environmental Bulletin 14, 185-188, 2005.

[10] Diyrikli, U., Mendil, D., Tuzen, M., Soylak, M, Elci, L., "Trace metal pollution from traffic in Denizli-Turkey during dry season” Biomedical Environmental Sciences 19, 254-261, 2006.

[11] Chen, C.M., Cheng, C.C., Chou, S.S. "Determination of $\mathrm{Cu}$ in edible oils by direct graphite furnace atomic absorption spectrometry” Food and Drug Analysis 7, 207-214, 1999.

[12] Chen, Q., Dong, H., "Solvent sublation using dithizone as a ligand for determination of trace elements in water samples" Microchimica Acta 150, 59-65, 2005.

[13] Asraf, W. "Accumulation of heavy metals in kidney and heart tissues of Epinephelus Microdon fish from the Arabian Gulf" Environmental Monitoring Assessment 101, 311-316, 2005.

[14] Fuh, C.B., Lin, H.I, Tsai, H.Y., "Determination of lead, cadmium, chromium and arsenic in 13 herbs of tocolysis formulation using atomic absorption spectrometry" Food ehehehand Drug Analysis 11, 39-45, 2003.

[15] Huang, W.B., "Heavy metal concentrations in the common benthic fishes caught from the coastal waters of eastern Taiwan” Food and Drug Analysis 11, 324-330, 2003.

[16] Narin, I., Tuzen, M., Sari, H., Soylak, M., "Heavy metal content of potato and corn chips from Turkey" Bulletin of Environmental Contamination and Toxicology 74, 1072-1077, 2005.

[17] Demalsy, F., Vincet, B., Beaulieu, F., "Mineral content and geographical origin of Canadian honey" Apidologie 20, 77-91, 1989.

[18] Miret, G., Terrab, M.L., Hernanz, A., Recamales, D.F., Heredia, M.A., "Multivariate correlation between color and mineral composition of honeys and by their botanical origin" Agriculture and Food Chemistry 53, 2574-2580, 2005.

[19] Sevlimli, H., Bayulgen, H., Varinioglu, N., "Determination of trace elements in honey by INAA in Turkey" Radio analytical Nuclear Chemistry Letter 165, 319-325, 1992.

[20] Bogdanov, S., Jurendic, T., Sieber, R., Gallmann, P., "Honey for nutrition and health: A review" American College of Nutrition 27, 677-689, 2008.

[21] Molan, P.C., "Honey for oral health” Dental Research 80 (special issue) 1-13, 2001.

[22] Steinberg, D., Kaine, G., Gedalia, G., "Antibacterial effect of propolis and honey on oral bacteria" American Journal of Dentistry 9, 236-239, 1996.

[23] Armon, P.J., "The use of honey in the treatment of infected wounds” Tropical Doctor 10, 91, 1980.
[24] Cavanagh, D., Ostapowicz, J., Ostapowicz, F. "Radical operation for carcinoma of the vulva” Obstetrics and Gynecology 77, 10371040, 1970.

[25] Munstedt, K., Sheybani, B., Hauenschild, B., Bruggmann, A., Bretzel, D., Winter, D., "Effects of basswood honey, honeycomparable glucose-fructose solution, and oral glucose tolerance test solution on serum insulin, glucose, and C-peptide concentrations in healthy subjects” Journal of Medicinal Food 11, 424-428, 2008.

[26] Khali, M.I., Sulaiman, S.A., Boukraa L., "Antioxidant properties of honey and its role in preventing health disorder" The Open Nutraceuticals 3, 6-16, 2010.

[27] Erbilir, F., Erdogrul, O., "Determination of heavy metals in honey in Kahramanmaras city, Turkey" Environmental Monitoring and Assessment 109, 1-3, 2005.

[28] Chen, L.Z., Rui, Y.K., Zhao, J., Ye, Z.H., Xue, X.F., Wang, P., "Application of ICP-MS to detection of trace elements and heavy metals in different kinds of honey" Guang Pu Xue Yu Guang Pu Fen Xi 28, 1403-1405, 2008.

[29] Sanna, G., Maria, I.P., Paola, C.P., "Determination of heavy metals in honey by anodic stripping voltammetry at microelectrodes” Analytical Chimica Acta 415, 165-173, 2000.

[30] Bratu, L., Georgescu, C., "Chemical contamination of bee honey identifying sensor of the environment pollution" Central European Agriculture 6, 467-470, 2005.

[31] Ioannidou, M.D., Zachariadis, G.A., Anthemidis, A.N., Stratis, J.A., Direct determination of toxic metals in honey and sugar using ICP-AES” Talanta 65, 92-97, 2005.

[32] Fredes, C., Montenegro, G., "Heavy metal and other trace elements contents in Chilean honey" Ciencia e Investigacion Agrarian 33, 50-58, 2006.

[33] Quan, S.X., Jum, T., Guang-guo, X., "Determination of trace elements in water, sea water and biological samples by ICP-AES after pre-concentration with ammonium pyrrolidinedithiocarbamate precipitation" Analytical Chimica Acta 3, 259-263, 1988.

[34] Devillers, J., Dore, J.C., Marenco, M., Ducnene, F.P., “Chemometrical analysis of 18 metallic and non-metallic elements found in honeys in France" Agriculture Food Chemistry 50, 5998-6007, 2002.

[35] Tuzen, M., Soylak, M., "Trace heavy metal levels in microwave digested honey samples from middle Anatolia, Turkey” Food and Drug Analysis 13, 343-347.

[36] Conti, M.E., Botre, F., "Honeybees and their products as potentia bioindicators of heavy metals contamination" Environmental Monitoring and Assessment 69, 267-282, 2001.

[37] Buldini, P.L., Ricci, L., Sharma, J.L., "Recent applications of sample preparation techniques in food analysis" Journal of Chromatography A 975, 47-70, 2002.

[38] Haswell, S.J., Atomic absorption spectrometry, Theory, Design and Applications, Elsevier, Amsterdam 1991.

[39] Reynolds, R.J., Atomic absorption spectroscopy, Barnes and Noble Inc, New York 1970.

[40] Flaten, T.P., "Aluminium as a risk factor in Alzheimer's disease, with emphasis on drinking water" Brain Res. Bull. 55, 187-196, 2001.

[41] Chakir, A., Romne, A., Barbagianni, N., Bartoli, D., Ferrazzi, P., "Major and trace elements in different types of Moroccan honeys" Basic and Applied Sciences 5, 223-231, 2011.

[42] Juliana, R.A., Lilyana, Y.D., Maria, L.A., "Palynological, physical and chemical data on honey from the Kazanlak region (Central Bulgaria)" Phytologia Balcanica 15, 107-114, 2009.

[43] Cantarelli, M.A., Pellerano, R.G., Marchevsky, E.J., Camina, J.M., "Quality of honey from Argentina: Study of chemical composition and trace elements” Argentine Chemical Society 96, 33-41, 2008.

[44] Madejczyk, M., Baralkiewicz, D., "Characterization of polish rape and honeydew honey according to their mineral contents using ICP-MS and FAAS / AES” Anal. Chim. Acta 617, 11-17, 2008.

[45] Tuzen, M., "Determination of some metals in honey samples for monitoring environmental pollution” Frensius Environmental Bull 11, 366-370, 2002.

[46] Hernandez, O.H., Fraga, J.M.G., Jimenez, A.I., Jimenez, F., Arias, J.J., "Characterization of honey from the Canary Islands: Determination of the mineral content by atomic absorption spectrophotometry" Food Chemistry 93, 449-458, 2005.

[47] Bogdanov, Haldimann, M., Luginbuhl, W., Gallmann, P., "Minerals in honey: environmental, geographical and botanical aspects” Apicultural Research and Bee World 46, 269-275, 2007. 
[48] Ferrer, S.D., Rodriguez, G.O.D., Martinez, J.P.J., Moran, M., "Mineral content of the honey produced in Zulia state" Venezuela, Alan 60, 70-79, 2010.

[49] Matei, N., Birghila, S., Dobrinas, S., Capota, P., "Determination of vitamin $\mathrm{C}$ and some trace elements $(\mathrm{Ni}, \mathrm{Mn}, \mathrm{Fe}, \mathrm{Cr})$ in Bee products” Acta. Chim. Slov 51, 169-175, 2004.

[50] Yilmaz, H., Yavuz, O., "Content of some trace metals in honey from South Eastern Anatolia” Food chemistry 65, 475-476, 1999.

[51] Conti, M.E., "Lazio region (Central Italy) honeys: a survey of mineral content and typical quality parameters" Food Control 11, 459-463, 2000.

[52] Pisani, Protano G., Riccobono, F., "Minor and trace elements in different honey types produced in Siena County (Italy)" Food Chemistry 107, 1553-1560, 2008.
[53] Przbylowski, P., Wilczynska, A., "Honey as an environmental marker” Food Chemistry 74, 289-291, 2001.

[54] Belouali, H., Bouakra, M., Hakkou, A.A., "Determination of some major and minor elements in the east of Morocco honeys through inductively coupled plasma optical emission spectrometry" Apicata 43, 17-24, 2008.

[55] Osman, K.A., Al-Doghairi, M.A., Al-Rehiavani, S., Helal, M.I.D., "Mineral contents and physicochemical properties of natural honey produced in Al-Qassim region, Saudi Arabia” Food Agriculture and Environment 5, 142-146, 2007.

[56] Al-Khalifa, A.S., Al-Arify, I.A., "Physicochemical characteristics and pollen spectrum of some Saudi honeys" Food Chemistry 67, 21-25, 1999.

[57] Samimi, A., Maymand, O.E., "Determination of Cadmium and Arsenic pollution by bee honey based on the study on Ja'far abad area from Saveh city from Iran” Water and Geoscience 199-2. 